\title{
Impact of a pharmacist-driven antimicrobial stewardship program in a private hospital in Costa Rica
}

\author{
José Pablo Díaz-Madriz, ${ }^{1}$ Eugenia Cordero-García, ${ }^{2}$ José Miguel Chaverri-Fernández, ${ }^{2}$ \\ Esteban Zavaleta-Monestel, ${ }^{1}$ Josué Murillo-Cubero, ${ }^{3}$ Hellen Piedra-Navarro, ${ }^{2}$ Marian Hernández- \\ Guillén, ${ }^{2}$ and Tiffany Jiménez-Méndez ${ }^{2}$
}

Suggested citation Díaz-Madriz JP, Cordero-García E, Chaverri-Fernández JM, Zavaleta-Monestel E, Murillo-Cubero J, Piedra-Navarro H, et al. Impact of a pharmacist-driven antimicrobial stewardship program in a private hospital in Costa Rica. Rev Panam Salud Publica. 2020;44:e57. https://doi.org/10.26633/RPSP.2020.57

ABSTRACT Objective. To measure the impact generated by the implementation of the pharmacy-driven antimicrobial stewardship program of the Clínica Bíblica Hospital.

Methods. This is a retrospective observational study that evaluates the consumption of antibiotics for the periods before and during implementation of the Clínica Bíblica Hospital antimicrobial stewardship program, calculated by means of defined daily dose per 1000 patient-days and days of therapy per 1000 patient-days. In addition, bacterial resistance patterns for the periods 2014-2015 and 2016-2017 were compared.

Results. Consumption of most-used antibiotics was calculated, looking for trends that might be associated with the activities implemented by the Clínica Bíblica Hospital antimicrobial stewardship program. Comparing some of the antibiotics with the highest consumption in periods I and II, use of levofloxacin and ceftriaxone showed a decrease of 54.0\% ( $p<0.001)$ and 14.6\% ( $p=0.003)$, respectively, whereas there was an increase in the use of cefazolin of $4539.3 \%$ ( $p<0.001)$. Regarding percentage of bacterial resistance, in most bacterial isolates no statistically significant changes were observed between the two periods.

Conclusions. A reduction in the overall consumption of antibiotics has been achieved over time, most likely attributable to the antimicrobial stewardship program. However, this trend was not observed for all the antibiotics studied. The pattern of resistance among the commonly isolated microorganisms did not vary greatly between the periods studied, which suggests that either the antimicrobial stewardship program may have prevented an increase in bacterial resistance since its implementation, or that it is too soon to see impact on bacterial resistance.

Keywords Antimicrobial stewardship; anti-infective agents; drug utilization; drug resistance, microbial; Costa Rica.

Antimicrobials are a group of successful drugs that have allowed a radical change in the health landscape, reducing historical morbidity and mortality by preventing infectious diseases from being the main cause of death (1-3).

However, in recent decades the indiscriminate use and abuse of these drugs in animals and humans has generated problems, including adverse reactions in patients, leading to an increase

\footnotetext{
Hospital Clínica Bíblica, San José, Costa Rica. $₫$ José Pablo Díaz-Madriz, jp.diazm27@gmail.com

2 University of Costa Rica, San Pedro, Costa Rica
}

of unnecessary expenses for the health system and the appearance of bacterial resistance (4-9).

Health centers are an ideal setting for the appearance of multidrug-resistant bacteria (7). Antimicrobial stewardship programs (AMS) have been established to address this problem, and to set standards and guidelines for health care professionals (10). 
The aim of this study was to measure the impact generated by the AMS of the Clínica Bíblica Hospital (AMS-HCB), one of the first hospitals in Central America to implement this initiative. The AMS-HCB is pharmacy driven and works without restrictions on the use of antimicrobials. The main practices implemented by this program are prospective audit and feedback, clinical guidelines development, and educational sessions.

\section{MATERIALS AND METHODS}

This is a retrospective observational study conducted at the Clínica Bíblica Hospital, a 68-bed private health center located in San José, Costa Rica. The records of patients who received antibiotic therapy with any of the following medications were analyzed: meropenem, ertapenem, moxifloxacin, levofloxacin, ciprofloxacin, cefuroxime, ceftriaxone, ceftazidime, cefazolin, cefalotin, vancomycin, ampicillin/sulbactam, and linezolid.

The consumption levels for the period before implementation of the AMS, or period I (April 2013-March 2015), and during the implementation of the AMS, or period II (April 2015-March 2017), were determined by calculating the defined daily dose $\left(\mathrm{DDD}^{1}\right)$ per 1000 patient-days and days of therapy $\left(\mathrm{DOT}^{2}\right)$ per 1000 patient-days $(1,11-13)$. The results for both periods were compared using IBM SPSS software. When calculating the values of DDD per 1000 patient-days and DOT per 1000 patient-days, the monthly average of each of the antibiotics was calculated and subjected to a descriptive statistical analysis. The Kruskal-Wallis nonparametric test was performed (14-16).

In addition, bacterial resistance patterns were compared for the periods 2014-2015 and 2016-2017. These patterns were based on the resistance reports on bacteria cultivated in the hospital during these periods, as reported by the Clínica Bíblica Hospital's Clinical Laboratory and Infection Prevention Committee. The resistance reports were obtained from the VITEK- $2^{\circledR}$ automated identification and antibiotic susceptibility testing system. These data were analyzed using the chi-squared test, to identify statistically significant changes in resistance that might be associated with the implementation of the AMS.

Regarding the data analysis, the first isolate of each infectious episode was considered, as well as the verification of the data by a microbiologist, and recommendations issued by the Clinical and Laboratory Standards Institute (CLSI) and the Spanish Society of Infectious Diseases and Clinical Microbiology (SEIMC) $(17,18)$.

For Pseudomonas aeruginosa and Enterococcus faecalis, elimination of some reports of resistance was required, due to the fact that they might have intrinsic resistance for some of the antibiotics studied. In addition, the report of colistin resistance was eliminated for all bacteria, as it is a more restricted antibiotic and requires a comprehensive analysis of each case before its use (19).

Information for the study was obtained from the electronic clinical records from the Clínica Bíblica Hospital's Hospitalized Patients Management system, Integrated Hospital Management System, and pharmacy records. The bacterial identification and

DDD is a clinical parameter established by the World Health Organization that represents the average daily dose of an antibiotic for a standard patient.

DOT is defined as the number of days a patient has received antibiotics regardless of the prescribed dose. resistance test results were also extracted through the computer system, along with other patient data of interest to the study. There was also access to the physical clinical records of these patients, as necessary.

It is important to mention that the ethical use of the data and patient confidentiality were guaranteed at all times. This work was approved by the Clínica Bíblica Hospital and the Scientific Ethics Committee of the University of Costa Rica (VI-3253-2018).

\section{RESULTS}

\section{DDD}

With the data obtained from the study, a DDD calculation was made for every 1000 patient-days for the 13 most-used antibiotics in the hospital. Table 1 compares the average use of antibiotics in the Clínica Bíblica Hospital in the two periods. Broad-spectrum antibiotics such as quinolones, thirdgeneration cephalosporins, and carbapenems were found to be the most widely used.

Comparing the four antibiotics with the highest consumption in periods I and II, the DDD per 1000 patient-days for levofloxacin showed a decrease of $54.0 \%(\mathrm{p}<0.001)$. Similarly, although with a smaller magnitude of change, ceftriaxone use decreased by $14.6 \%$ ( $p=0.003$ ), while the decrease in ciprofloxacin use was not statistically significant $(1.5 \%, \mathrm{p}=0.47)$. In contrast, there was a statistically significant increase in the use of ertapenem by $15.6 \%(\mathrm{p}=0.041)$.

Although their consumption was lower, there was an upward trend in use of some of the reduced-spectrum antibiotics following the implementation of the AMS-HCB. Such was the case for cefazolin and cefuroxime, which showed a significant increase in the DDD per 1000 patient-days of $4539.3 \%(p<0.001)$ and $406.4 \%$ ( $p<0.001)$, respectively. In addition, there were statistically significant decreases in the consumption of cefalotin

TABLE 1. Comparison of the changes in average of consumption as measured by DDD per 1000 patient-days for the hospitalized population between periods I and II in Clínica Bíblica Hospital

\begin{tabular}{|c|c|c|c|c|c|}
\hline & & & D/1 000 patient & -days & \\
\hline & Period I & Period II & $\begin{array}{l}\text { Magnitude of } \\
\text { change }\end{array}$ & $\%$ & $\bar{p}$ \\
\hline Amp/sulb & 119.5 & 123.3 & $\mathbf{\Delta} 3.8$ & $\mathbf{\Delta} 3.2$ & 0.741 \\
\hline Cefalotin & 26.4 & 18.9 & $\nabla 7.5$ & $\nabla 28.4$ & 0.006 \\
\hline Cefazolin & 1.1 & 49.4 & $\Delta 48.3$ & $\Delta 4539.3$ & $<0.001$ \\
\hline Ceftazidime & 27.0 & 25.2 & $\nabla 1.8$ & $\nabla 6.6$ & 0.523 \\
\hline Ceftriaxone & 223.3 & 190.6 & $\nabla 32.7$ & $\nabla 14.6$ & 0.003 \\
\hline Cefuroxime & 26.0 & 131.6 & $\boldsymbol{\Delta} 105.6$ & $\Delta 406.4$ & $<0.001$ \\
\hline Ciprofloxacin & 218.8 & 215.6 & $\nabla 3.2$ & $\nabla 1.5$ & 0.470 \\
\hline Ertapenem & 151.3 & 174.9 & $\mathbf{\Delta} 23.6$ & A 15.6 & 0.041 \\
\hline Levofloxacin & 325.6 & 149.9 & $\nabla 175.7$ & $\nabla 54.0$ & $<0.001$ \\
\hline Linezolid & 69.0 & 79.8 & A 10.8 & $\mathbf{\Delta} 15.5$ & 0.174 \\
\hline Meropenem & 108.4 & 86.8 & $\nabla 21.6$ & $\nabla 19.9$ & 0.076 \\
\hline Moxifloxacin & 84.1 & 80.8 & $\nabla 3.3$ & $\nabla 3.9$ & 0.496 \\
\hline Vancomycin & 74.7 & 56.1 & $\nabla 18.6$ & $\nabla 25.0$ & 0.029 \\
\hline
\end{tabular}


and vancomycin by $28.4 \%(\mathrm{p}=0.006)$ and $25.0 \%(\mathrm{p}=0.029)$, respectively.

\section{DOT}

For the 13 most-used antibiotics, calculated as DOT per 1000 patient days, between period I and period II there was an apparent reduction of $3.2 \%(\mathrm{p}=0.108)$. This is equivalent to that calculated by DDD per 1000 patient-days, 3.2\% $(\mathrm{p}=0.174)$, both not statistically significant.

According to DOT per 1000 patient-days, there was a highly significant decrease in consumption of ceftriaxone and levofloxacin, by $19.1 \%(\mathrm{p}<0.001)$ and $49.9 \%(\mathrm{p}<0.001)$, respectively (Table 2). There was also a statistically significant decrease in the consumption of meropenem and vancomycin, by $19.1 \%$ $(p=0.02)$ and $30.7 \%(p=0.005)$, respectively. On the other hand, there was a significant increase of $17.4 \%(p=0.037)$ in the consumption of ertapenem, the antibiotic with the second highest DOT per 1000 patient-days in both periods I and II. This is similar to the results obtained according to DDD per 1000 patient days.

In addition, there were other important changes for cefazolin consumption, with an increase of $2215.1 \%$ ( $p<0.001$ ), and for cefuroxime, with an increase of $309.8 \%(p<0.001)$. These results are consistent with the data for DDD per 1000 patient-days.

\section{Antibiotic resistance}

The bacteria with greater clinical relevance or a greater number of isolates were analyzed for each period (Table 3) and the number of final strains isolated obtained, which was then used to perform comparisons of antibiotic resistance profiles for each bacteria.

An example of the analysis done for each of the bacteria is shown in Table 4, which presents the resistance profile of Staphylococcus epidermidis against a range of antibiotics for the periods 2014-2015 and 2016-2017. A highly significant decrease in the resistance of $S$. epidermidis to rifampicin was observed with a magnitude of change of $36 \%(\mathrm{p}<0.001)$. In addition, significant differences were found in the resistance of $E$. faecalis to gentamicin, a decrease of $18 \%(\mathrm{p}=0.032)$; as well as a decrease in resistance of Staphylococcus haemolyticus to rifampicin (44\%, $\mathrm{p}=0.004)$, and an increase in resistance to trimethoprim/sulfamethoxazole $(36 \%, \mathrm{p}=0.038)$. For the rest of the bacteria, no statistically significant changes were found in the percentages of resistance comparing the two periods.

\section{DISCUSSION}

In 2015, the Clínica Bíblica Hospital implemented a pharmacistdriven antimicrobial stewardship program $(20,21)$, the AMSHCB. Since its implementation, it has been constantly and actively monitored by a multidisciplinary team consisting of a clinical pharmacist (director), an infectious disease physician, a microbiologist, and the hospital's assistant chief medical officer.

In 2015, when high levels of consumption of broadspectrum antibiotics were detected in the hospital, one of the main problems was the incorrect use of ceftriaxone and levofloxacin in surgical prophylaxis. The AMS team executed educational activities to promote greater use of first-generation cephalosporins such as cefazolin, since these were the drugs of
TABLE 2. Comparison of the changes in average consumption as measured by DOT per 1000 patient-days for the hospitalized population between periods I and II in Clínica Bíblica Hospital

\begin{tabular}{|c|c|c|c|c|c|}
\hline & & & DT/1 000 patien & -days & \\
\hline & Period I & Period II & $\begin{array}{l}\text { Magnitude of } \\
\text { change }\end{array}$ & $\%$ & $\bar{p}$ \\
\hline Amp/sulb & 51.0 & 43.3 & $\boldsymbol{\nabla} 7.8$ & $\nabla 15.2$ & 0.364 \\
\hline Cefalotin & 32.8 & 26.0 & $\nabla 6.8$ & $\boldsymbol{\nabla} 20.7$ & 0.055 \\
\hline Cefazolin & 2.2 & 50.1 & $\Delta 48.0$ & $\boldsymbol{\Delta} 2215.1$ & $<0.001$ \\
\hline Ceftazidime & 23.8 & 25.7 & $\Delta 1.9$ & $\Delta 7.8$ & 0.711 \\
\hline Ceftriaxone & 265.1 & 214.5 & $\boldsymbol{\nabla} 50.6$ & $\nabla 19.1$ & $<0.001$ \\
\hline Cefuroxime & 2.0 & 8.0 & $\Delta 6.1$ & A 309.8 & $<0.001$ \\
\hline Ciprofloxacin & 48.3 & 57.6 & $\Delta 9.3$ & $\mathbf{\Delta} 19.3$ & 0.274 \\
\hline Ertapenem & 125.1 & 146.9 & $\Delta 21.8$ & $\Delta 17.4$ & 0.037 \\
\hline Levofloxacin & 74.3 & 37.2 & $\boldsymbol{\nabla} 37.1$ & $\nabla 49.9$ & $<0.001$ \\
\hline Linezolid & 44.1 & 61.0 & $\Delta 16.9$ & $\Delta 38.4$ & 0.039 \\
\hline Meropenem & 80.7 & 65.3 & $\nabla 15.4$ & $\nabla 19.1$ & 0.020 \\
\hline Moxifloxacin & 42.4 & 47.1 & $\Delta 4.7$ & $\mathbf{\Delta} 11.1$ & 0.496 \\
\hline Vancomycin & 71.3 & 49.4 & $\nabla 21.9$ & $\nabla 30.7$ & 0.005 \\
\hline
\end{tabular}

DOT, days of therapy; Amp/sulb, ampicillin/sulbactam; $\mathbf{\nabla}$ decrease; $\boldsymbol{\Lambda}$ increase.
Source: Prepared by the authors based on data from Clínica Bíblica Hospital Antimicrobial Stewardship Program

TABLE 3. Frequency of isolation of the bacteria analyzed in Clínica Bíblica Hospital, 2014-2015 and 2016-2017

\begin{tabular}{|c|c|c|}
\hline & $\begin{array}{l}\text { Total strains isolated } \\
2014-2015^{\star}\end{array}$ & $\begin{array}{l}\text { Total strains isolated } \\
2016-2017^{*}\end{array}$ \\
\hline \multicolumn{3}{|l|}{ Gram-negative bacilli } \\
\hline Escherichia coli & 137 & 178 \\
\hline Pseudomonas aeruginosa & 87 & 94 \\
\hline Klebsiella pneumoniae & 48 & 62 \\
\hline $\begin{array}{l}\text { Stenotrophomonas } \\
\text { maltophilia }\end{array}$ & 20 & 13 \\
\hline \multicolumn{3}{|l|}{ Gram-positive cocci } \\
\hline Staphylococcus aureus & 81 & 78 \\
\hline Staphylococcus epidermidis & 45 & 51 \\
\hline Enterococcus faecalis & 35 & 37 \\
\hline $\begin{array}{l}\text { Staphylococcus } \\
\text { haemolyticus }{ }^{\star *}\end{array}$ & 16 & 15 \\
\hline
\end{tabular}

choice for surgical antibiotic prophylaxis, as indicated by the clinical guideline implemented at that time. These strategies explain the significant increase in the use of cefazolin (2 215.1\%, $\mathrm{p}<0.001)$ and the decrease in the consumption of ceftriaxone $(19.1 \%, p<0.001)$, and partially explain the decrease of levofloxacin $(49.9 \%, \mathrm{p}<0.001)$, according to the consumption calculated in DOT (Figure 1). Ertapenem is another antibiotic that was recommended to be avoided in surgical prophylaxis, as well as in a wide number of other indications. However, this is the only antibiotic that did not show a reduction in consumption. On the contrary, it increased over time $(17.4 \%, \mathrm{p}=0.037)$. This suggests that different strategies are needed in order to control the overprescription of ertapenem.

The decrease in the consumption of meropenem (19.1\%, $\mathrm{p}=0.02)$ represents valuable progress in the initiative to 
TABLE 4. Comparison of the reports of antibiotic resistance for Staphylococcus epidermidis in Clínica Bíblica Hospital, 2014-2015 and 2016-2017

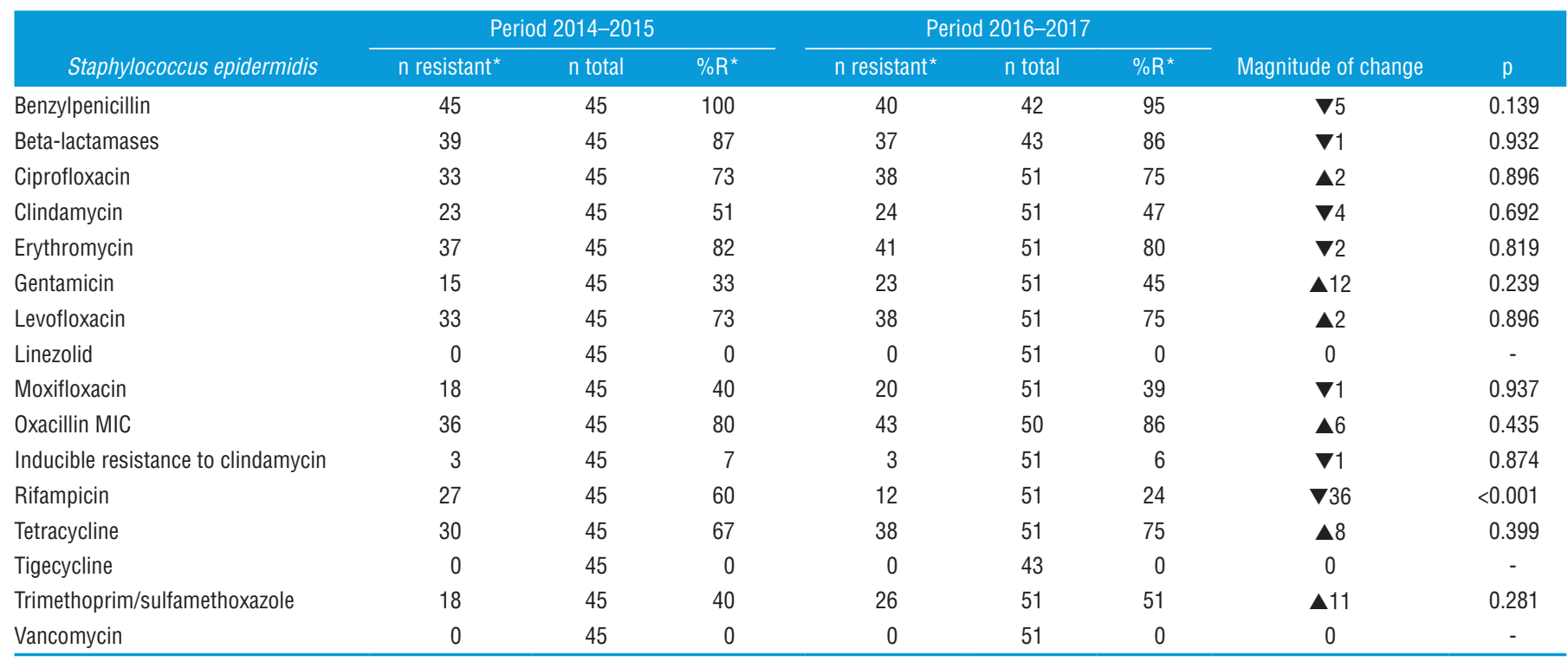

$\mathrm{R}$, resistance; n, number of isolations; $\boldsymbol{\nabla}$ decrease; $\boldsymbol{\Delta}$ increase.

* Includes resistant strains with intermediate sensitivity.

(-) Statistical significance was not calculated because the resistance of this bacteria to these antibiotics is a constant.

Source: Prepared by the authors based on data from Clínica Bíblica Hospital Antimicrobial Stewardship Program

FIGURE 1. Trend in the trimester averages of days of therapy (DOT) per 1000 patient days for cefazolin and ceftriaxone in Clínica Bíblica Hospital for the period 2013-2017, before and during implementation of the antimicrobial stewardship program

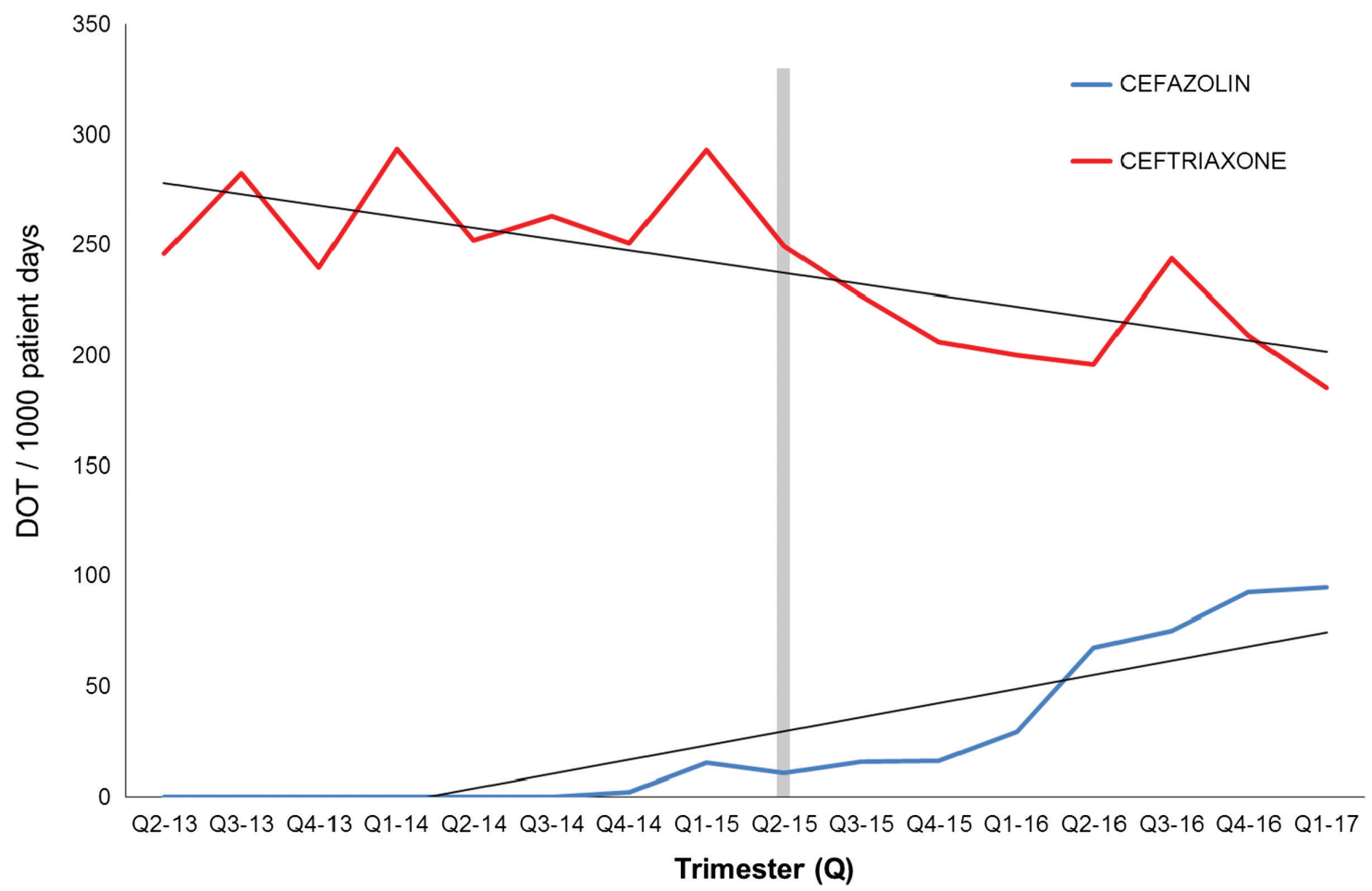

Source: Prepared by the authors based on data from Clínica Bíblica Hospital Antimicrobial Stewardship Program

improve the use of antimicrobials, since meropenem is considered an antibiotic of last resort. Regarding P. aeruginosa, its resistance to meropenem has increased in the country; thus, strategies to optimize the use of this antibiotic and of all carbapenems should be reinforced (22). Multiple studies have compared the relationship between the consumption of antibiotics and the reported rates of resistance. In the case of $P$. aeruginosa, it has a high capacity to acquire new resistance 
mechanisms under selective antibiotic pressure, including loss of outer membrane proteins, efflux pumps, and production of certain beta-lactamases, among others. In vitro and in vivo studies have documented that exposure to carbapenems increases the risk of carbapenem-resistant $P$. aeruginosa, which is also associated with cross-resistance to other antibiotics (23).

On the other hand, the consumption of linezolid increased $(38.4 \%, \mathrm{p}=0.039)$, while vancomycin consumption decreased $(30.7 \%, p=0.005)$. This change can be related to the preferences of the prescriber, since these are two antibiotics that are used for Gram-positive infections. Linezolid may be preferred over vancomycin based on some reports that show similar activity for meticillin-resistant Staphylococcus aureus specific infections with less nephrotoxicity. It is also dosed easier than vancomycin, which must be adjusted according to the pharmacokinetic profile of each patient. In addition, conversion to oral administration is easily performed in the case of linezolid, and no dosage adjustment is necessary in case of renal failure. Its resistance profile has not changed and it remains 100\% sensitive (24-26).

One of the main reasons why AMSs are necessary in hospitals is the constant growth of resistance (27). A non-increase in resistance, as shown in the results, is considered a positive result, suggesting that the actions of the AMS are having an impact on physicians' prescriptions. However, it is necessary to continue monitoring the effects over time, since positive and conclusive results usually are seen in a 4.8-year period after the intervention $(28,29)$. Despite the few significant changes regarding the patterns of resistance in this study, a longer follow-up period is generally required to appreciate changes in the microbiota of a hospital center $(28,29)$.

Some limitations include the design of the study, since it cannot assure that the AMS is the direct cause or the only cause of the changes described in the results. Variations in the level of antimicrobial resistance can also be influenced by the actions of the hospital's Infection Prevention Committee, as well as other factors external to this hospital, such as the use of antibiotics in other health facilities.

Nonetheless, when determining the consumption by means of DDD per 1000 patient-days and DOT per 1000 patient-days, it is evident that reductions in the overall consumption of antibiotics have been achieved over time, possibly attributable to AMS implementation. However, this is not a common trend for all antibiotics, and the continuation of the program should be evaluated in the near future. The development and implementation of more clinical guidelines is the next step to cover more antibiotics used in the hospital setting.

Author contributions. All authors contributed to the study design, data analysis and interpretation, and writing of the paper. All authors reviewed and approved the final version.

\section{Conflicts of interest. None declared.}

Disclaimer. Authors hold sole responsibility for the views expressed in the manuscript, which may not necessarily reflect the opinion or policy of the RPSP/PAJPH and/or the Pan American Health Organization.

\section{REFERENCES}

1. Rodríguez-Baño J, Paño-Pardo J, Alvarez-Rocha L, Asensio A, Calbo E, Cercenada E, et al. Programas de optimización de uso de antimicrobianos (PROA) en hospitales españoles: documento de consenso GEIH-SEIMC, SEFH y SEMPSPH. Farm Hosp. 2012;36(1):33e1-33.e30.

2. Tijerino A, Jiménez A, Bolaños H, Chanto G, Acuña MT, Vargas $\mathrm{J}$, et al. Informe de vigilancia: Bacterias causantes de infecciones comunitarias de importancia en salud pública y su resistencia a los antimicrobianos, Costa Rica 2010. Tres Ríos: INCIENSA; 2011 [cited 2019 Jan 15]. Available from: https://www.inciensa.sa.cr/ vigilancia_epidemiologica/informes_vigilancia/2010/Bacterias/ Resistencia $\% 20$ a $\% 201$ os $\% 20$ antibioticos $\% 20$ en $\% 20$ germenes $\% 20$ comunitarios\%20-\%202010.pdf

3. Organización Panamericana de la Salud. Informe anual de la Red Latinoamericana de Monitoreo de la Vigilancia de la Resistencia a los Antibióticos. Washington, DC: OPS; 2013 [cited 2019 Feb 4]. Available from: https://www.paho.org/hq/dmdocuments/2010/2010-Informe-anual-RELAVRA-1.pdf

4. Kollef MH. Inadequate antimicrobial treatment: an important determinant of outcome for hospitalized patients. Clin Infect Dis. 2000;31(Suppl 4):S131-S138.

5. Centers for Disease Control and Prevention. Antibiotic resistance threats in the United States, 2013. CDC; 2013 [cited 2019 Feb 4]. Available from: https://www.cdc.gov/drugresistance/threat-report2013/

6. Castro-Sánchez E, Moore LS, Husson F, Holmes AH. What are the factors driving antimicrobial resistance? Perspectives from a public event in London, England. BMC Infect Dis. 2016;16:465.

7. Alós J. Resistencia bacteriana a los antibióticos: una crisis global. Enferm Infecc Microbiol Clin. 2015;33(10):692-9.

8. Magiorakos A, Srinivasan A, Carey RB, Carmeli Y, Falagas ME, Giske CG, et al. Multidrug-resistant, extensively drug-resistant and pandrug-resistant bacteria: an international expert proposal for interim standard definitions for acquired resistance. Clin Microbiol Infect. 2012;18(3):268-81.

9. Ugalde-Espiñeira J, Bilbao-Aguirregomezcorta J, Sanjuan-López AZ, Floristán-Imízcoz C, Elorduy-Otazua L, Viciola-García M. Programa de optimización del uso de antimicrobianos (PROA). Experiencia en un hospital secundario. Rev Esp Quimioter. 2016;29(4):183-9.

10. Molano Franco D, Rojas Gambasica JA, Beltrán Garcés CA, Nieto Estrada VH, Valencia Moore AA, Jaller Bornacelli YE, et al. Implementación de un programa de uso racional de antibióticos en cuidado intensivo: ¿se pueden mejorar los resultados? Acta Colomb Cuid Intensivo. 2018;18(2):71-6.

11. Leuthner KD, Doern GV. Antimicrobial stewardship programs. J Clin Microbiol. 2013;51(12):3916-20.

12. Association for Professionals in Infection Control and Epidemiology. Antimicrobial stewardship [Internet, cited 2019 Mar 5]. https:/ /apic.org/Professional-Practice/Practice-Resources/Anti microbial-Stewardship

13. Barlam TF, Cosgrove SE, Abbo LM, MacDougall C, Schuetz AN, Septimus EJ, et al. Implementing an antibiotic stewardship program: guidelines by the Infectious Diseases Society of America and the Society for Healthcare Epidemiology of America. Clin Infect Dis. 62(19):e51-e77.

14. Field A. Discovering statistics using SPSS. 3rd ed. London: SAGE; 2009.

15. Martínez González MA, Sánchez Villegas A, Faulín Fajardo FJ. Bioestadística amigable. 2nd ed. Madrid: Elsevier; 2006.

16. Castañeda MB, Cabrera AF, Navarro Y, de Vries W. Procesamiento de datos y análisis estadísticos utilizando SPSS. Porto Alegre: EdiPUCRS; 2010.

17. Clinical and Laboratory Standards Institute. Performance standards for antimicrobial susceptibility testing. 28th ed. Wayne, PA: CLSI; 2018:1-16. 
18. Calvo Montes J, Canut Blasco A, Martínez Martínez L, Rodríguez Díaz JC. Preparación de informes acumulados de sensibilidad a los antimicrobianos. 51. Procedimientos en Microbiología Clínica. Cercenado Mansilla E, Cantón Moreno R (editors). Sociedad Española de Enfermedades Infecciosas y Microbiología Clínica. Madrid: SEIMC; 2014:5-11.

19. Bennett JE, Dolin R, Blaser MJ. Mandell, Douglas, and Bennett's principles and practice of infectious diseases. Philadelphia: Saunders; 2015.

20. Duguid M. Pharmacists and antimicrobial stewardship. J Pharm Pract Res. 2011;41(2):92-4.

21. Royal Pharmaceutical Society. The pharmacy contribution to antimicrobial stewardship. London: Royal Pharmaceutical Society; 2017 Sep [cited 2019 Feb 4]. Available from: https: / www.rpharms.com/ Portals/0/RPS\%20document $\% 20$ library/Open $\% 20$ access/Policy/ AMS\%20policy.pdf

22. Jimenez A, Rodriguez D, Baltodano P, Bolaños H; Red Nacional de Laboratorios de Bacteriología. Informe técnico: Vigilancia de la resistencia a los antibióticos de Pseudomonas aeruginosa, 20132017. Tres Ríos, Costa Rica: INCIENSA; 2018 [cited 2019 Feb 20]. Available from: https://www.inciensa.sa.cr/vigilancia_epidemiologica/informes_vigilancia/2019/Bacterias/INCIENSA \%20-\%20 Vigilancia\%20de\%20RAM\%20de\%20P.\%20aeruginosa\%2020132017.pdf

23. Zou YM, Ma Y, Liu JH, Shi J, Fan T, Shan YY, et al. Trends and correlation of antibacterial usage and bacterial resistance: time series analysis for antibacterial stewardship in a Chinese teaching hospital (2009-2013). Eur J Clin Microbiol Infect Dis. 2015;34(4):795-803.

24. Rybak MJ, Lomaestro BM, Rotscahfer JC, Moellering RC, Craig WA, Billeter M, et al. Vancomycin therapeutic guidelines: a summary of consensus recommendations from the Infectious Diseases Society of America, the American Society of Health-System Pharmacists, and the Society of Infectious Diseases Pharmacists. Clin Infect Dis. 2009;49(3):325-7.

25. An MM, Shen H, Zhang JD, Xu GT, Jiang YY. Linezolid versus vancomycin for meticillin-resistant Staphylococcus aureus infection: a meta-analysis of randomised controlled trials. Int J Antimicrob Agents. 2013;41(5):426-33.

26. Ardanuy C, Cercenado E, Morosini MI, Torres C. Detección fenotípica de mecanismos de resistencia en grampositivos. 39. Procedimientos en Microbiología Clínica. Cercenado E, Cantón R (editors). Sociedad Española de Enfermedades Infecciosas y Microbiología Clínica. Madrid: SEIMC; 2011:11-12.

27. Morris AM. Antimicrobial stewardship programs: appropriate measures and metrics to study their impact. Curr Treat Options Infect Dis. 2014;6(2):101-12.

28. Taggart LR, Leung E, Muller MP, Matukas LM, Daneman N. Differential outcome of an antimicrobial stewardship audit and feedback program in two intensive care units: a controlled interrupted time series study. BMC Infect Dis. 2015;15:480.

29. Bertollo LG, Lutkemeyer DS, Levin AS. Are antimicrobial stewardship programs effective strategies for preventing antibiotic resistance? A systematic review. Am J Infec Control. 2018; 46(7):824-36.

Manuscript received on 25 October 2019. Revised version accepted for publication on 2 April 2020.

\section{Impacto de un programa de optimización del uso de antimicrobianos conducido por la farmacia de un hospital privado en Costa Rica}

RESUMEN Objetivo. Medir el impacto de la ejecución de un programa de optimización del uso de antimicrobianos conducido por la farmacia del Hospital Clínica Bíblica.

Métodos. En este estudio retrospectivo y de observación se evaluó el consumo de antibióticos antes y después de la ejecución del programa de optimización del uso de antimicrobianos en el Hospital Clínica Bíblica. El consumo se calculó tomando como base la dosis diaria por 1.000 días-paciente y los días de tratamiento por 1.000 días-paciente. Además, se compararon los perfiles de resistencia bacteriana en los períodos 2014-2015 y 2016-2017.

Resultados. Se calculó el consumo de los antibióticos más usados para establecer las tendencias que podrían estar relacionados con las actividades ejecutadas por el programa de optimización del uso de antimicrobianos del Hospital Clínica Bíblica. Se compararon algunos de los antibióticos de mayor consumo en los períodos I y II, el uso de la levofloxacina y la ceftriaxona mostró una disminución de 54,0\% $(p<0,001)$ y $14,6 \%(p=0,003)$, respectivamente, mientras que se evidenció un aumento en el uso de la cefazolina de $4.539,3 \%(p<0,001)$. Con respecto al porcentaje de resistencia bacteriana, no se encontró ningún cambio estadísticamente significativo entre los dos períodos para la mayoría de las cepas bacterianas aisladas.

Conclusiones. Con el transcurso del tiempo se ha logrado una disminución en el consumo de antibióticos en general, probablemente relacionada con el programa de optimización del uso de antimicrobianos. Sin embargo, esta tendencia no se observó en todos los antimicrobianos analizados. No se evidenció una variación significativa en los patrones de resistencia entre los microorganismos aislados comúnmente entre los períodos comparados, lo que puede significar dos cosas: que el programa de optimización del uso de antimicrobianos podría haber evitado un aumento de resistencia bacteriana desde que se puso en marcha o que es demasiado pronto para que se evidencie un impacto en la resistencia bacteriana.

Palabras clave Programas de optimización del uso de los antimicrobianos; antiinfecciosos; utilización de medicamentos; farmacorresistencia microbiana; Costa Rica. 


\section{Impacto de um programa de gerenciamento do uso de antimicrobianos por profissionais farmacêuticos em um hospital particular na Costa Rica}

RESUMO Objetivo. Mensurar o impacto da implantação de um programa de gerenciamento do uso de antimicrobianos por profissionais farmacêuticos em um hospital particular.

Métodos. Trata-se de um estudo observacional retrospectivo para avaliar o uso de antibióticos no período anterior e posterior à implantação do programa de gerenciamento do uso de antimicrobianos no Hospital Bíblica Clínica, em San José, Costa Rica. O consumo dos medicamentos foi calculado com base na dose diária definida por 1.000 pacientes-dia e dias de tratamento por 1.000 pacientes-dia. Foi realizada uma comparação dos padrões de resistência bacteriana entre os períodos 2014-2015 e 2016-2017.

Resultados. O consumo dos antibióticos mais utilizados foi calculado visando identificar possíveis tendências associadas às ações do programa de gerenciamento do uso de antimicrobianos implantado no hospital. A comparação do consumo de alguns dos antibióticos mais utilizados no primeiro e no segundo períodos considerados apontou uma redução de $54,0 \%$ no uso de levofloxacina $(p<0,001)$ e $14,6 \%$ no uso de ceftriaxona $(p=0,003)$, com um aumento de $4.539,3 \%$ no uso de cefazolina $(p<0,001)$. Com relação à resistência bacteriana, não se observou variação estatisticamente significativa na maioria dos isolados bacterianos entre os dois períodos.

Conclusões. Houve redução no consumo de antibióticos em geral, provavelmente atribuível ao programa de gerenciamento do uso de antimicrobianos. Porém, esta mesma tendência não foi observada para todos os antibióticos estudados. Não houve variação importante no padrão da resistência dos microrganismos mais frequentemente isolados entre os períodos estudados. Isso indica que o programa de gerenciamento do uso de antimicrobianos implantado possivelmente evitou o aumento da resistência bacteriana ou que é ainda muito cedo para se observar o impacto na resistência bacteriana.

Palavras-chave Gestão de antimicrobianos; anti-infecciosos; uso de medicamentos; resistência microbiana a medicamentos; Costa Rica. 